\title{
EFFECT OF TEMPERATURE ON THE LIFE CYCLE AND PREDATORY CAPACITY OF LADYBIRD BEETLE MICRASPIS DISCOLOR FABRICIUS (COLEOPTERA: COCCINELLIDAE)
}

\author{
Bui Minh Hong*, Tran Thi Thanh Binh, Vu Thi Thu Hang \\ Hanoi National University of Education, *bui_minhhong@yahoo.com
}

\begin{abstract}
The effects of temperature on the development and the predatory capacity of Micraspis discolor larvae were studied in laboratory. Two temperature levels $23.50^{\circ} \mathrm{C}$ and $30.71^{\circ} \mathrm{C}$ on average, were used to assess the life cycle and developmental stages of the ladybird beetle $M$. discolor. The life cycle of $M$. discolor was 27.38 days at $23.50^{\circ} \mathrm{C}$ and reduced to 19.77 days at $30.71^{\circ} \mathrm{C}$, the total larval period was 13.42 and 9.9 days, respectively. The pre-oviposition period of the ladybird beetle $M$. discolor was 4.95 days at $23.50^{\circ} \mathrm{C}$ and 5.23 days at $30.71^{\circ} \mathrm{C}$. The female beetles laid 282 eggs and the hatching percentage of egg was 81.03 at $30.71^{\circ} \mathrm{C}$ and 179 eggs and the hatching percentage of egg was 88.73 at $23.50^{\circ} \mathrm{C}$. At temperature $30.71^{\circ} \mathrm{C}$ and $23.50^{\circ} \mathrm{C}$, the pupal periods were 4.91 and 2.92 days, respectively. The longevity of adult ladybird beetles was slightly prolonged when they were reared at $30.71{ }^{\circ} \mathrm{C}$ compared with that when they were reared at $23.50^{\circ} \mathrm{C}$. Feeding on the second insturs of B. brassicae the predatory capacity of M. discolor larvae consumed an average 206.28 prey per day at $30.71^{\circ} \mathrm{C}$ and 161.84 prey per day at $23.50^{\circ} \mathrm{C}$.
\end{abstract}

Keywords: Micraspis discolor, life cycle, longevity, predatory beetle.

\section{INTRODUCTION}

The ladybird beetle have been known worldwide as a predator of a number of insects. They are distributed in many countries of Asia [6]. This beetle, often called ladybug or coccinellid, is the most commonly known of all beneficial insects.

In Europe these beetles are called ladybirds [16]. They are of great economic important as predaceous both in their larval and adult stages on various important crop pests such as aphids, coccids and other soft bodied insects including aphids [5, 7], while the species $M$. discolor feed on many inscet pests such as aphids, brown plant hopper, corn borer, Lepidopteron insects, mealybug, white flies [13]. This predaceous coccinellids is also found in association with those insects infesting cruciferous vegetables, cabbage, bean, chilli, tobacco, cotton, maize, potato, soyabean and sweet potato [4].

In Vietnam, the aphid is one of the most destructive pests and its distribution is field wide. The aphids that attack cruciferae plants and other crops in the surrounding of Hanoi city. At the time of infestation plants fail to give planting resulting in 20-40\% yield loss [12]. In balanced ecosystems, insect pests are kept in check by their natural enemies (predators and parasitoids). They are considered as beneficial agents in agricultural systems. Coccinellid predators play an important role in keeping aphid densities low in cruciferous vegetables and other field crops.

The study of the biology of $M$. discolor would help to use this insect of proper biological control. So, the present study was undertaken to observe the biology and the effect of temperature to the life cycle and predatory capacity of M. discolor.

\section{MATERIALS AND METHODS}

\section{Collection and mass culture}

All experiments were done in the Faculty of Biology, Hanoi National University of Education, Vietnam, at room temperature to observe the biology of ladybird beetle. The temperature was measured in the morning and afternoon of the day by electronic thermometers humidity.

M. discolor were collected from various cruciferous crops, such as Brassica oleracea var. capitata, Brassica chinensis L, Brassica oleracea var. botrytis L, Brassica oleracea var. gongylodes in Gia Lam, Thanh Tri and Dong Anh districts, Vietnam. 
Several males and females of the Micrapis discolor were collected by sweep net from the crucifer field and were confined in cages. These beetles were paired and capulated in cages $(18 \times$ $13.5 \times 6.5 \mathrm{~cm})$. The bottom of the cages was covered with blotting paper.

Brevicoryne brassicae collected from cruciferous plants in the fields. After that they have reared in cruciferous plants place in rearing sheft boxes until the second instars emerged.

\section{Effects of temperatures on the developmental stages of M. discolor}

The larvae and predator adults of Micrapis discolor were reared in the laboratory in order to supply necessary insects for the experiments, Several males and females of the Micrapis discolor were collected by sweep net from the crucifer field and were confined in cages. These beetles were paired and copulated in cages (18 $\times 13.5 \times 6.5 \mathrm{~cm})$. The bottom of the cages was covered with blotting paper. Immediately after hatching, larvae were transfered to the rearing cages $(18 \times 13.5 \times 6.5 \mathrm{~cm})$ and the second instars of Brevicoryne brassicae were provided as food on leaf cuttings of cruciferous crops with rearing method.

Brevicoryne brassicae collected from cruciferous plants in the fields. After that they were reared in cruciferous plants placed in rearing sheft boxes until the second instars emerged. The number of aphids was counted everyday in order to additional food for larvae and predator adult of Micrapis discolor until pupation. Temperatures for rearing were room temperature, with $80 \%$ relative humidity.

Eggs were observed daily for eclosion, larvae were observed in Petri dishes, the feeding process of 30 larvae and fresh cruciferous leaves provided daily until pupation. Pupae were observed daily for adult emergence and sex ratio was determined. Eggs, larvae, pupae were also collected daily and preserved in $70 \%$ ethanol solution.

\section{Effects of temperatures on the longevity of adult}

After emerged from pupae adults were transfered to the rearing cages. Two experiments were carried out and randomly triplicate: Experiment 1: at $30.71^{\circ} \mathrm{C}$ (room temperature), experiment $2: 23.50^{\circ} \mathrm{C}$ (room temperature).

Each experiment was tracking 30 individual adults, food was provided daily and testing laboratory until adults died. Time tracking of adult life in each experimental plot were recorded.

\section{Feeding capacity of $M$. discolor larvae on B. brassicae}

Immediately after hatching, the larvae and predator adults of $M$. discolor were taken and reared individualy in Petri dishes $(6.0 \times 1.0 \mathrm{~cm})$. The predator larva of $M$. discolor were tracking 15 individuals and candomly triplicate 3. Each predator larva of $M$. discolor was offered 150 second instar larvae of Brevicoryne brassicae every day. The number of prey eaten daily and the development time of the predator larva of M. discolor were recorded.

\section{Statistical analysis}

The Data were analyzed by Analysis of Variance (ANOVA) and the mean values were separated by Duncan's Multiple Range Test (DMRT). All analyses were performed using Descriptive statistics.

\section{RESULTS AND DISCUSSION \\ Effects of temperatures on the developmental stages of $M$. discolor}

Effects of two temperature levels $23.50^{\circ} \mathrm{C}$ and $30.71^{\circ} \mathrm{C}$ used on the life cycle and developmental stages of the ladybird beetle M. discolor were showed in table 1 .

\section{First instar}

The development of newly hatched larvae was $1.44 \pm 0.16$ days at $30.71{ }^{\circ} \mathrm{C}$ and $1.89 \pm$ 0.17 day at $23.50^{\circ} \mathrm{C}$. Chowdhury et al. (2008) [3] found that the newly hatched larval period was from 1 to 3 days and on an average of 1.71 \pm 0.20 days using bean aphid as food, which is similar to the results of our findings at $23.50^{\circ} \mathrm{C}$.

Prodhan et al. (1995) [11] reported that this period of $M$. discolor was 2 to 3 days using bean aphid, which is higher than our findings. 
Table 1. Effects of temperatures on the developmental stages of M. discolor on B. brassicae

\begin{tabular}{|c|c|c|}
\hline \multirow{2}{*}{ Developmental stage } & \multicolumn{2}{|c|}{ Duration (days) at two levels of temperature $\left({ }^{\circ} \mathrm{C}\right)$} \\
\cline { 2 - 3 } & 30.71 & 23.50 \\
\hline Egg & $2.00 \pm 0.00$ & $3.82 \pm 0.06$ \\
\hline First instar & $1.44 \pm 0.16$ & $1.89 \pm 0.17$ \\
\hline Second instar & $2.04 \pm 0.24$ & $2.32 \pm 0.18$ \\
\hline Third instar & $2.52 \pm 0.26$ & $3.54 \pm 0.17$ \\
\hline Fourth instar & $3.90 \pm 0.24$ & $5.67 \pm 0.24$ \\
\hline Total larval period & $9.9 \pm 0.23$ & $13.42 \pm 0.19$ \\
\hline Pupa & $2.92 \pm 0.25$ & $4.91 \pm 0.12$ \\
\hline Pre-Oviposition & $4.95 \pm 0.15$ & $5.23 \pm 0.14$ \\
\hline Total life cycle & $19.77 \pm 0.44$ & $27.38 \pm 0.15$ \\
\hline
\end{tabular}

\section{Second instar}

The duration of the $2^{\text {nd }}$ instar larvae was $2.04 \pm 0.24$ days at $30.71^{\circ} \mathrm{C}$ and $2.32 \pm 0.18$ day at $23.50^{\circ} \mathrm{C}$ (table 1 ). Nasiruddin \& Islam (1979) [8] found that the duration of the $2^{\text {nd }}$ instar larvae of $M$. discolor was 2.4 to 3.1 days on different aphid. Prodhan et al. (1995) [11] found that the duration of $2^{\text {nd }}$ instar of $M$. discolor varied from 1 to 2 days using bean aphid using cabbage aphid as a host, which is comparatively similar to the results of the present findings.

Chowdhury et al. (2008) [3] reported that the duration of the $2^{\text {nd }}$ instar larvae of M. discolor varied from 1.50 to 3 days and the mean duration was $2.20 \pm 0.16$ days using bean aphid.

\section{Third instar}

The result indicated that the duration of the 3rd instar larvae was $2.52 \pm 0.26$ days $\left(30.71^{\circ} \mathrm{C}\right)$ and $3.54 \pm 0.17$ days $\left(23.50^{\circ} \mathrm{C}\right) \quad($ table 1$)$. Nasiruddin and Islam (1979) [8] reported that the duration of the $3^{\text {rd }}$ instar larvae of $M$. discolor varied from 3.1 to 3.8 days on maize, bean and chilli aphids as host. Chowdhury et al. (2008) [3] found that the duration of the $3^{\text {rd }}$ instar larvae lasted from 2 to 4 days. The mean duration of $3^{\text {rd }}$ instar larvae was $3.10 \pm 0.17$ days.

\section{Fourth instar}

Observation made on the larval duration of the $4^{\text {th }}$ instar larvae on an average $3.90 \pm 0.24$ days with temperature 30.71 and $5.67 \pm 0.24$ days with temperature 23.50 (table 1). Prodhan et al. (1995) [11] reported that the duration of final instar larvae of $M$. discolor was 3 days.
Nasiruddin \& Islam (1979) [8] recorded that the duration of the $4^{\text {th }}$ instar larvae of $M$. discolor varied from 3.8 to 4.2 days on maize, bean and chilli aphids.

\section{Duration of larval stages}

The total larval period (1st instar to $4^{\text {th }}$ instar) was $9.9 \pm 0.23$ days at $30.71^{\circ} \mathrm{C}$ and $13.42 \pm 0.19$ days at $23.50^{\circ} \mathrm{C}$ (table 1$)$. Nasiruddin \& Islam (1979) [8] observed that the total period of $M$. discolor was 11.8 to 12.5 days, which is simillar to the present findings. Prodhan et al. (1995) [11] observed that the total larval period of $M$. discolor varied from 7 to 9 days on bean aphid. This result was lower than the present study.

However, Sakurai et al. (1991) [14] reported that the quality of food and environmental factors like temperature, humidity also play an important role on different aspects of the biology of coccinellid beetles. So, this variation may be due to the quality of food and environmental factors like temperature and humidity.

\section{Pupal period}

The pupal period was $2.92 \pm 0.25$ days at $30.71^{\circ} \mathrm{C}$ and $4.91 \pm 0.12$ days at $23.50^{\circ} \mathrm{C}$ (table 1). Nagammuang (1987) [9] recorded that the mean pupal duration of $M$. discolor was $3.43 \pm$ 0.57 days when larvae reared on $A$. craccivora. Different findings revealed that the pupal period of coccinellid beetles varied with the different of food and it was correlated with the temperature [14]

Pre-Oviposition 
The time between the date of adult emergence and the first egg deposition was considered as pre-oviposition period. The preovipositon period of $M$. discolor was $4.95 \pm$ 0.15 days at $30.71^{\circ} \mathrm{C}$ and $5.23 \pm 0.14$ days at $23.50^{\circ} \mathrm{C}$ (table 1$)$.

Agarwala et al. (1988) [1] observed that the pre-oviposition period was 6 to 10.33 days on A. craccivora at $16-26^{\circ} \mathrm{C}$. Prodhan et al. (1995)
[11] studied that the pre-oviposition preiod of M. discolor was 3 to 7 days.

\section{Adult longevity}

The longevity of adult ladybird beetles was counted from the emergence of the adult to its death. At $30.71^{\circ} \mathrm{C}$, the longevity of the ladybird beetles was $32 \pm 0.15$ days, and at $23.50^{\circ} \mathrm{C}$ the longevity of the ladybird beetles was $22 \pm 0.14$ days (table 2).

Table 2. Effects of temperatures on the longevity of adult

\begin{tabular}{|c|c|}
\hline Average temperature $\left({ }^{\circ} \mathrm{C}\right)$ & The longevity of adult (days) \\
\hline 30.71 & $32 \pm 0.15$ \\
\hline 23.50 & $22 \pm 0.14$ \\
\hline
\end{tabular}

It showed that the longevity of the ladybird beetle at $23.50^{\circ} \mathrm{C}$ was shorter than that at $30.71^{\circ} \mathrm{C}$.

Samal \& Misra (1985) [15] reported that the adult of $M$. discolor fed on Nilaparvata lugens lived for 24 to 40 days in September-November. Ngammuang (1987) [9] found that the longevity of male and female were $37.8 \pm 15.24$ and 59.53 \pm 23.53 days when fed on A. craccivora, in the laboratory at temperature of $28 \pm 2^{\circ} \mathrm{C}$ with $74 \%$ RH.

\section{Fecundity and hatching rate of $M$. discolor}

In the laboratory, the number of eggs laid per female were 348. The mean hatching percentage were 83.03 at temperature of $30.71^{\circ} \mathrm{C}$ and the number of eggs laid per female were 222 . The mean hatching percentage were 88.73 at temperature of $23.50^{\circ} \mathrm{C}$ (table 3 ).

Table 3. Effects of temperatures on the fecundity and hatching rate of $M$. discolor

\begin{tabular}{|l|c|c|}
\hline \multirow{2}{*}{ No. of observation } & \multicolumn{2}{|c|}{ Average temperature $\left({ }^{\circ} \mathrm{C}\right)$} \\
\cline { 2 - 3 } & 30.71 & 23.50 \\
\hline No. of egg laid & 348 & 222 \\
\hline No. of egg hatched & 282 & 197 \\
\hline$\%$ of egg hatching & 81.03 & 88.73 \\
\hline
\end{tabular}

Ngammuang (1987) [9] reported that the number of eggs deposited by on female of M. discolor was $181.07 \pm 6.37$ on A. craccivora, and $70.15 \%$ eggs were hatched. Prodhan et al. (1995) [11] observed that the facundity of female varied form 200-300 eggs with mean of 270.5 and with average $70.15 \%$ eggs were hatched. These results seem to be close with our findings.

Omkar \& Pervez (2002) [10] reported that the oviposition peak tended to shift towards younger females and the oviposition rate increased with increase in temperature from 20 to $27^{\circ} \mathrm{C}$. The maximum fecundity and percent egg viability was 750 eggs and $95 \%$ at $27^{\circ} \mathrm{C}$ and minimum 385 eggs and $65 \%$ at $20^{\circ} \mathrm{C}$, respectively, that is higher than the present findings.

Feeding capacity of $M$. discolor larvae on B. brassicae

The results presented in table 4 show the predatory capacity of $M$. discolor larvae of each stage on $B$. brassicae was assessed at two rearing temperatures.

The predatory capacity of first instar larvae was lowest, eating an average 16.89 prey per day at $30.71^{\circ} \mathrm{C}$ and 14.54 prey per day at $23.50^{\circ} \mathrm{C}$. The capacity of the second instar larvae was eating an average 33.82 prey per day at $30.71^{\circ} \mathrm{C}$ and 27.23 prey per day at $23.50^{\circ} \mathrm{C}$. 
Table 4. Feeding capacity of M. discolor larvae on B. brassicae

\begin{tabular}{|c|c|c|}
\hline $\begin{array}{l}\text { Developmental } \\
\text { stage }\end{array}$ & $\begin{array}{l}\text { Average temperature } \\
\left({ }^{\circ} \mathrm{C}\right)\end{array}$ & $\begin{array}{l}\text { Predatory capacity of different instars } \\
\text { of } M \text {. discolor (prey/day) }\end{array}$ \\
\hline First instar & \multirow{5}{*}{30.71} & $16.89 \pm 1.15$ \\
\hline Second instar & & $33.82 \pm 0.78$ \\
\hline Third instar & & $63.40 \pm 1.22$ \\
\hline Fourth instar & & $92.17 \pm 1.50$ \\
\hline Total preys eaten & & $206.28 \pm 1.66$ \\
\hline First instar & \multirow{5}{*}{23.50} & $14.54 \pm 0.19$ \\
\hline Second instar & & $27.23 \pm 0.26$ \\
\hline Third instar & & $47.90 \pm 0.28$ \\
\hline Fourth instar & & $72.17 \pm 1.50$ \\
\hline Total preys eaten & & $161.84 \pm 0.62$ \\
\hline
\end{tabular}

The capacity of the third instar larvae was slightly higher, eating an average 63.40 prey per day at $30.71^{\circ} \mathrm{C}$ and 47.90 prey per day at $23.50^{\circ} \mathrm{C}$. At the fourth instar stage, the larvae had the highest predatory capacity, eating an average of 92.17 prey per day at $30.71{ }^{\circ} \mathrm{C}$ and 72.17 prey per day at $23.50^{\circ} \mathrm{C}$. In total, each lavrae can eat an average 206.28 prey per day at $30.71^{\circ} \mathrm{C}$ and 161.84 prey per day at $23.50^{\circ} \mathrm{C}$.

Begum et al. (2002) [2] reported that each larva of $M$. discolor consumed an average of 47.6 third instar brown plant hopper.

\section{CONCLUSION}

Rearing temperature affected both growth and development of M. Discolor, the cycle of this species was prolonged at low temperature.

The feeding capacity of $M$. discolor larvae was significantly greater at $30.71^{\circ} \mathrm{C}$ than at $23.50^{\circ} \mathrm{C}$. The data from this work also provided further evidence that temperature has affected adult longevity and fecundity and hatching rate of M. discolor.

\section{REFERENCES}

1. Agarwala B. K., Das S., Senchowdhuri M., 1988. Biology and food relation of Micraspis discolor (F.) an aphidophagous coccinellid in India. J. Aphidology, 2(1-2): 7-17.

2. Begum M. A., Mahbuba J., Bari M. N., Hossain M. M., Afsana N., 2002. Potentiality of Micraspis discolor (F.) as a
Biological Control of Nilaparvata lugens (Stal). Online Journal of Biological Sciences, 2(9): 630-632.

3. Chowdhury S. P., Ahat M., Amin M. R., Hasan S. M., 2008. Biology of ladybird beetle Micraspis discolor F. (Coleoptera: Coccinellidae). Int. J. Sustain. Crop Prod., 3(3): 39-44.

4. Gautam R. D., Chander S., Sharma V. K., Singh R., 1995. Aphids infesting safflower, their predatory complex and effect on oil content. Ann. Plant Prot. Sci., 3: 27-30.

5. Hippa H., Kepeken S. D., Laine T., 1978. On the feeding biology of Coccinella hieroglyphica L. (Coleoptera: Coccinellidae). Kevo-subaretitic Ras. Station, 14: 18-20.

6. Islam M. A., Nasiruddin M., 1978. Life history and feeding habit of Verania discolor (F.) Bangladesh. J. Biol. Sci., 6+7(I): 48-49.

7. Kring T. J., Gilstrap F. E., Michels G. J., 1985. Role of indegenous coccinellid in regulating green bugs (Homoptera: Aphididae) on Texas grain sorghum. J. Econ. Ent., 78(1): 269-273.

8. Nasiruddin M., Islam M. A., 1979. Verania discolor F. (Coleoptera: Cocinellidae) an effective predator on different species of aphid. Bangladesh J., 6(1): 69-71.

9. Ngammuang, Pa-Nan, 1987. Study on the coccinellidae, Micraspis discolor (F.) 
(Coleoptera: Coccinellidae) and its role as biological control agent. Bankok (Tailand).

10. Omkar, Pervez A., 2002. Influence of Temperature on Age-Specific Fecundity of the Ladybeetle Micraspis discolor (Fabricius). International Journal of Tropical Insect Science, 22(1): 61-65. Published online: 19 September 2011.

11. Prodhan N. Z. H., Haque M. A., Khan A. B., Rahman A. K. M. M., 1995. Biology of M. discolor (F.) (Coleoptera: Coccinellidae) and its susceptibility to two insecticides. Bangladesh J. Ent., 5(1-2): 11-17.

12. Quach Thi Ngo, 2000. Study on the aphis (Homoptera: Aphididae) on main crops at North Vietnam and control methods, Ph.D Dissertation, Hanoi Agricultural University, $152 \mathrm{pp}$.

13. Rao N. V., Reddy A. S., Rao K. T., 1989. Natural enemies of cotton white fly Bemesia tabaci. Gunnandius in relation to host population and weather factors. J. Bio. Control., 3: 10-12.

14. Sakurai H., Yoshida N., Kobayashi C., Taheda S., 1991. Effect of temperature and day length on oviposition and growth of lady bird bettle, Coccinella septumpunctata Res. Bull. of the faculty of Agri. Gifu University, 56: 45-50.

15. Samal P., Misra B. C., 1985. Morphology and biology of the coccinellid beetle Verania discolor Fab. (Coleoptera: Coccinellidae) a predator on rice brown plant hopper Nilaparvata lugens (Stal). Oryza, 22(1): 58-60.

16. William F. L., 2002. Lady beetle. Ohio State University Extension Fact Sheet, Horticulture and Crop Science. Division of Wildlife, 2021 Coffey Rd. Columbus, Ohio43210-1086.

\title{
ẢNH HƯỞNG CỦA NHIỆT ĐỘ ĐẾN VÒNG ĐỜI VÀ KHẢ NĂNG ĂN MỒI CỦA BO RÙA ĐỎ MICRASPIS DISCOLOR FABRICIUS (COLEOPTERA: COCCINELLIDAE)
}

\author{
Bùi Minh Hồng, Trần Thị Thanh Bình, Vũ Thị Thu Hằng
}

Trường đại học Sư phạm Hà Nội

\section{TÓM TÁ́T}

Ảnh hưởng của 2 ngưỡng nhiệt độ $23,50^{\circ} \mathrm{C}$ và $30,71^{\circ} \mathrm{C}$ đến vòng đời và khả năng ăn của sâu non bọ rùa đỏ Micraspis discolor trong phòng thí nghiệm đã được nghiên cứu với con mồi là rệp xám.

Ở điều kiện nhiệt độ $23,50^{\circ} \mathrm{C}$, thời gian hoàn thành vòng đời của bọ rùa đỏ là 27,38 ngày, giai đoạn sâu non hoàn thành pha phát dục là 13,42 ngày, giai đoạn nhộng là 4,91 ngày; giai đoạn trước đẻ trứng của bọ rùa đỏ là 5,23 ngày, con cái đẻ 179 quả trứng và tỷ lệ trứng nở $88,73 \%$; khả năng ăn rệp $B$. brassicae là 161,84 con rệp/ngày.

Ở điều kiện nhiệt độ $30,71^{\circ} \mathrm{C}$, thời gian hoàn thành vòng đời của bọ rùa đỏ là 19,77 ngày, giai đoạn sâu non hoàn thành pha phát dục là 9,9 ngày; giai đoạn nhộng là 2,9 ngày; giai đoạn trước đẻ trứng là 4,95 ngày; con cái đẻ 288 quả trứng và tỷ lệ trứng nở $81,03 \%$; khả năng ăn rệp $B$. brassicae của sâu non là 206,28 con rệp/ngày.

Tù khóa: Micraspis discolors, khả năng ăn, nhiệt độ, vòng đời, thời gian sống.

Ngày nhận bài: 13-12-2012 